\title{
PENGENALAN PROSES CITRA SECARA DIGITAL
}

\author{
Oleh: \\ Suharto Widjojo \\ Adi Rusmanto \\ Suharjo
}

\section{ABSTRACT}

Remote sensing tecbnology has been growing rapidly in Indonesia since the early 1970. Many application bave been applied by government and private institution.

In the beginning the use of this technology. The interpretation that bas been applied by the users was visual interpretation. The use of digital analysis concide with the development of computer technology.

This paper aims to introduce the use of digital interpretation. By using this interpretation, the data can be integrated with geographical information system that grow continually in Indonesia.

\section{INTISARI}

Teknologi penginderaan jaub telab berkembang dengan pesat di Indonesia semenjak awal 1970-an. Berbagai jenis aplikasi telab diterapkan baik oleb instansi pemerintab maupun swasta.

Pada awal penggunaannya teknologi interpretasi yang dominan dipergunakan oleb para pemakai adalab interpretasi secara visual. Sejalan dengan perkembangan teknologi komputer, analisa citra berkembang pula ke arab digital.

Makalab ini mencoba mengenalkan teknologi interpretasi secara digital yang memungkinkan data tersebut diintegrasi dengan sistem informasi geografi yang terus berkembang di Indonesia.

\section{PENDAHULUAN}

Penerapan citra penginderaan jauh secara visual telah banyak dilakukan di Indonesia, baik oleh instansi pemerintah, swasta maupun oleh perguruan tinggi. Pemanfaatan citra penginderaan jauh secara digital sudah mulai dikenal dan dikembangkan.

Citra digital adalah informasi gambar yang disajikan dalam angka digital, mempunyai variasi antara 0 sampai dengan 255. Angka digital menyajikan perbedaan derajat keabuan (grey sca- le). Citra digital memberikan keuntungan dibandingkan dengan tipe informasi yang disajikan dalam bentuk visual. Format digital memberikan kemudahan untuk transfer, penyimpanan dan pemanggilan kembali data citra. Citra digital mempunyai kualitas radiometrik yang tinggi. Data digital dapat dianalisa dengan menggunakan komputer, karena data dalam bentuk numerik. Algorit$\mathrm{hm}$ yang sama digunakan untuk identifikasi citra digital akan memperoleh hasil yang sama pula (Baba, 1987). 
Proses citra digital adalah teknikteknik untuk melakukan manipulasi dari citra digital dengan menggunakan komputer. Proses citra digital melaksanakan perintah seperti penghapusan naan data, display dan pencetakan citra, manipulasi citra data serta managemen data. Operasi tersebut dapat dibagi menjadi tiga jenis yaitu: proses citra penajaman citra dan klasifikasi citra

Gambar 1

Diagram Alir Interpretasi Citra Secara Digital

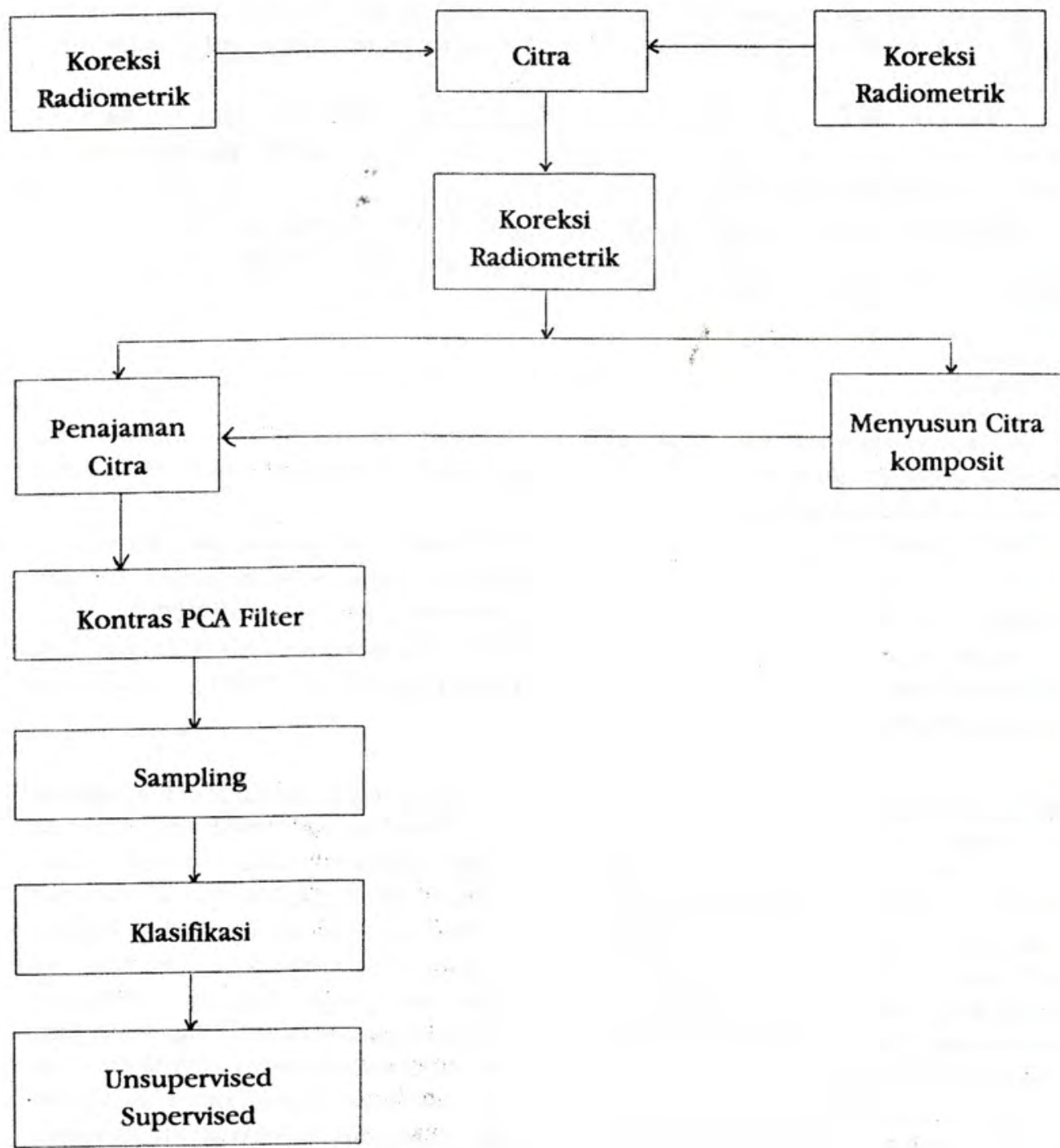

noise, koreksi citra baik koreksi radiometrik maupun geometrik, penajaman citra, ekstraksi informasi, penyederha-
(Sutanto, 1990). Gambar 1 menunjukkan diagram alir proses citra secara digital. 


\section{Proses Citra}

Kesalahan yang terjadi pada proses perolehan data dari suatu citra perlu dilakukan koreksi untuk mendapatkan citra yang bebas dari kesalahan. Koreksi adalah tahap awal dari setiap proses citra. Suatu citra perlu dikoreksi dari distorsi, degradasi dan noise yang terjadi selama proses untuk mendapatkan citra yang seakurat orisinilnya. Koreksi tersebut dibagi menjadi dua tipe yaitu koreksi radiometrik dan koreksi geometrik (Richards, 1987).

\subsection{Koreksi Radiometrik}

Respons yang non-linier dari detektor mengakibatkan kesalahan radiometrik pada citra digital. Area yang berbeda pada citra tidak selalu mengikuti hubungan yang sama antara angka digital dan radiasinya. Data citra perlu dikoreksi radiometrik. Garis drop-out dan n-line strip adalah kesalahan radiometrik yang sering terhadi pada citra penginderaan jauh orbital seperti Landsat atau SPOT. Garis drop-out terjadi ketika detektor tidak berfungsi pada saat scanning dilakukan. Kesalahan menyesuaikan posisi detektor akan mengakibatkan kesalahan pita n-line atau strip.

Pembiasan dan penyerapan atmosfir juga mempengaruhi kualitas data. Pembiasan atmosfir menambah ketajaman citra, sementara penyerapan atmosfir mengurangi ketajaman. Perubahan histogram dan metode analisa regresi membantu mengurangi pengaruh pembiasan atmosfir. Pengaturan detektor dapat dilakukan untuk mengatur absorbsi dengan model distorsi dengan bantuan stasiun meteorologi.

\subsection{Koreksi Geometrik}

Beberapa distorsi geometrik dapat terjadi padas citra karena sensor, bentuk lahan dan posisi sensor dalam perexaman gambar. Koreksi geometrik pada dasarnya adalah transformasi citra satelit agar sesuai dengan posisi sebenarnya/peta. Ini membantu dalam mencari sampel citra yang sesuai dengan sistem grid pada peta. Distorsi geometrik dalam citra satelit sering terjadi disebabkan oleh beberapa faktor, antara lain kesalahan arah scanning, rotasi bumi, proyeksi peta dan kesalahan scanning garis (Baba, 1987). Kebanyakan kesalahan tersebut dapat dihilangkan dari citra asal diketahui tentang sebab-sebab kesalahannya.

Perbedaan tingkat koreksi digunakan pada citra satelit untuk mengurangi kesalahan sistematik sebelum data digunakan oleh pemakai (users).

\section{Penajaman Citra}

Teknik citra menambah kualitas citra untuk interpretasi secara visual. Teknik tersebut sangat berguna karena banyak citra satelit tidak mempunyai cukup informasi ketika ditampilkan dalam layar monitor komputer. Beberapa teknik penajaman tersedia untu menambah kualitas citra. Penajaman citra dilakukan setelah citra dikoreksi secara radiometrik dan geometrik.

\subsection{Penambahan Kontras}

Kontras adalah karekteristik penting dalam citra dan membawa akibat yang kuat dalam penampilan citra untuk memudahkan dideteksi. Banyak citra satelit kekurangan kontras dan untuk kemudahan interpretasi diperlukan penambahan kontras. Pembiasan atmosfir, sistem sensor, dan karakteristik bentang lahan dapat menyebabkan kontras yang rendah. Teknik penambahan kontras antara lain dengan menambah selang (range) nilai ketajaman dari citra sehingga citra tersebut dapat ditampilkan pada layar komputer dan ciinterpretasi secara effisien. 
Nilai ketajaman diperoleh dari masukan citra yang kemudian ditambah secara seragam dalam bentuk linier yang sederhana, yang mudah untuk diimplementasi. Perenggangan (Stretch) secara linier mendapatkan perbedaan perenggangan ke perbedaan selang nilai ketajaman metode tersebut membantu untuk menambah kontrol citra tertentu ke dalam selang nilai ketajaman yang spesifik dibanding citra asli. Logarothm metode peregangan menggunakan logarithm hubungan antara input dan output nilai ketajaman untuk menambah kontras di bagian yang gelap dari citra. Eksponensial penambahan kontras terjadi di bagian yang paling kontras. Peregangan seragam, yang biasa disebut persamaan histogram, memberi lebih banyak kepada ketajaman nilai yang sering terjadi pada citra. Peregangan Gaussian mentransformasi histogram dari citra ke Gaussian distribusi, karena itu menghasilkan peregangan baik yang ke gelap maupun yang ke terang dari nilai ketajaman.

Algoritm dari penambahan kontras digunakan pada citra tergantung dari kepentingan interpreter. Histogram dari nilai ketajaman membantu dalam identifikasi areal yang menarik.

\subsection{Filter Spasial}

Filter spasial adalah filter dimana ketajaman nilai pada lokasi i,j pada output citra adalah fungsi dari beberapa nilai ketajaman sekitar $i, j$ pada input citra. Filter spasial merubaha data pada lokasi tertentu yang tergantung pada nilai yang terdapat di sekitarnya. Perbedaan nilai pembobotan menghasilkan filter yang berbeda untuk kepentingan yang tidak sama mengakibatkan low-pass, high-pass dan filter arah.

Filter low-pass menghaluskan citra dan menghilangkan noise dan jalur $\mathrm{n}$ - line, ini sering terjadi pada Landsat baik TM maupun MSS. High-pass filter digunakan untuk penambahan beda tinggi. Penajaman tepi membatasi beda tinggi, membuat tajam dan detail yang menyebabkan detail citra pada arah tertentu. Ini akan membantu dalam aplikasi seperti kelurusan geologi, ombak laut, dan kenampakan budidaya seperti jaring jalan dan batas. Tekstur filter memberi tanda variasi keabuan pada citra seperti halus atau kasar dan mempunyai aplikasi dalam bidang pemetaan geologi, hutan dan klasifikasi urban.

2.3Analisa Komponen Utama (Principal Component Analysis/PCA)

Data citra multispektral biasanya berkorelasi kuat antara panjang gelombang satu dengan lainnya. Analisa komponen Utama (PCA) adalah transformasi spasial yang mengoperasikan semua panjang gelombang bersama untuk membuat gerenalisasi data citra yang tidak berkorelasi dari data citra yang terkorelasi. PCA membuat generalisasi informasi yang berisi sejumlah besar panjang gelombang kedalam dua atau tiga transformasi komponen utama dari citra. Nilai Eigen dan vektor Eigen dari matriks covariant dari citra dihitung untuk implementasi analisa komponen utama (PCA). PCA digunakan sebagai taktik pre-klasifikasi untuk memudahkan proses analisa selanjutnya.

2.4Rasionalisasi Panjang Gelombang

Rasionalisasi panjang gelombang atau rasionalisasi spektral adalah teknik dimana dua atau tiga panjang gelombang dari citra dibagai dalam pixelpixel. Rasionalisasi panjang gelombang mempunyai beberapa keuntungan antara lain: (1) Menghilangkan faktor bias secara temporal maupun spektral. (2) Mengurangi variasi radiasi dari slope dan aspek topografinya dan (3) Pena- 
jaman radiant untuk dapat membedakan kenampakan antara tanah dan vegetasi.

Perbandingan detil citra biasanya dilakukan dengan membandingkan dua citra yang ditajamkan detilnya. Perbandingan antara MSS band 7 dan band 5 dapat memberikan informasi tentang jumlah vegetasi.

\section{Sampling}

Untuk dapat melakukan klasifikasi, komputer membutuhkan masukan dari pemakai berupa sampel-sampel obyek. Sampel tersebut dipilih oleh pemakai, berdasarkan tujuan dan kriteria dan klasifikasi yang telah ditentukan. Sampel yang dipilih oleh pemakai akan dibaca nilai spektralnya oleh komputer sekaligus pada beberapa saluran (apabila pengambilan sampel dilakukan pada citra komposit berwarna). Setelah pengambilan sampel selesai, maka komputer akan membaca nilai spektral pada keseluruhan pixel dalam citra untuk penentuan klas-klasnya.

\section{Klasifikasi Citra}

Klasifikasi citra adalah teknik kuantitatif. Perbedaan tahap dalam klasifikasi citra adalah sebagai berikut:

- Observasi dari atribut atau karakteristik obyek

- Pemilihan kenampakan penting dari beberapa pengukuran

- Membuat klasifikasi

- Evaluasi dari hasil klasifikasi

Kenampakan medan yang menghasilkan kontras spektral secara besar memudahkan untuk melakukan klasifikasi. Perubahan besar dalam data citra menunjukkan perubahan dalam tipe penutup, sementara fluktuasi yang tidak menentu menunjukkan tipe subklas penutup dan kondisi yang sulit untuk melakukan klasifikasi dari masingmasing tipe penutup.
Faktor dominan yang menyebabkan variasi data adalah pembiasan atmosfir, topografi, sudut penyinaran matahari, klas campuran dan variabel antar klas. Faktor tersebut menghasilkan overlap spektral antar klas. Dua jenis metode digunakan dalam klasifikasi citra: sipervised dan unsupervised. Klasifikasi supervised menggunakan sampel yang diketahui identitasnya untuk membuat keputusan baru. Klasifikasi unsupervised membagi data ke dalam perbedaan klas spektral berdasarkan pengukuran persamaan spektral.

\subsection{Klasifikasi Supervised}

Dalam klasifikasi supervised, survey lapangan, interpretasi foto udara dan peta digunakan untuk identifikasi training area yang representatif untuk masing-masing klas yang dinginkan. Training area harus mempunyai nilai variabel yang representatif untuk masingmasing klas dan harus sampel yang homogen. Perhitungan statistik seperti mean, covariant dihitung dalam masing-masing klas. Jumlah yang cukup untuk sampel area harus ada dalam masing-masing klas untuk memperkirakan nilai selang klas secara akurat. Biasanya, diperlukan minimal 30 training pixel setiap klas untuk mendapatkan klas statistik yang dapat dipercaya.

Pengambilam keputusan klas menggunakan satu diantara tiga teknik yaitu, jarak minimun, pipa paralel dan maksimum likelihood.

Klas mean vektor digunakan dalam jarak minimum ke rata-rata klasifikasi. Pixel dalam citra digunakan untuk klas yang terdekat dengan vektor rata-rata. Metode tersebut sederhana dan memberikan hasil klasifikasi yang bagus kalau ada beberapa klas yang homogen. 
Pipa pararel atau klasifikasi box adalah klasifikasi yang paling populer bagi remote sensing dan yang paling cepat dan effisien. Box atau pipa paralel diletakkan di sekitar masing-masing rata-rata klas. Biasanya tiga standard deviasi sekitar nilai rata-rata dalam setiap spektral panjang gelombang digunakan untuk menentukan box. Pixel dalam citra diklasifikasi dengan box dan akan terjadi overlap antar box kalau klas spektralnya sama dan ada korelasi yang tinggi antara pemilikan spektral dari obyek dalam panjang gelombang yang berbeda. *

Klasifikasi maximum likelihood adalah yang paling mahal dan biasanya adalah klasifikasi yang paling akurat. Metode tersebut menggunakan informasi tentang statistik covariant vektor rata-rata dari klas. Penyebaran data dalam masing-masing klas dideskripsikan dengan fungsi distribusi normal. Klasifikasi dibuat dengan memilih klas dimana pixel mempunyai kemungkinan terbesar dari anggotanya.

Dari masing-masing metode tersebut di atas, adalah mungkin untuk memisahkan pixel yang tidak diketahui identitasnya dengan aplikasi yang benar, biasanya digunakan dalam standard deviasi.

\subsection{Klasifikasi Unsupervised}

Klasifikasi unsupervised digunakan kalau data tambahan pada studi area tidak tersedia. Group data yang mempunyai nilai spektral seragam diidentifikasi dengan menggunakan algoritm clustreing. Algoritm K-means biasanya digunakan untuk membentuk kelompok. Dibandingkan interpretasi foto udara, yang merupakan teknik kualitatif, komputer dalam melaksanakan klasifikasi secara kuantitatif, akurat dan dapat diulang.

\section{Kesimpulan}

Citra digital pada tahun-tahun terakhir ini banyak digunakan karena fleksibel, tersedia dalam berbagai teknik dan harga yang tidak mahal dari data citra digital tersebut.

Sejalan dengan pengembangan teknologi analisa citra secara digital perlu dikembangkan pula sistem informasi geografi (BIS/SIG) karena sistem informasi geografi digunakan untuk mengintergrasikan data penginderaan jauh dengan data spasial yang lain seperti data tanah, hasil survey, data topografi dan untuk menjawab pertanyaan yang lebih komplek.

\section{Referensi}

Baba, J. Sai., Principles of Digital Image Processing in Remote Sensing for Urban Survevys and Human Settlements Analysis, Dehra Dun, India: The Indian Institute of remote Sensing and the ESCAP/UNDP Regional Remote Sensing Programme, 1987.

Richards, John A., Remote Sensing Digital Image Analysis, An Introduction, New York: Springer - Verlag Berlin Heidelberg, 1986).

Sutanto. ed., Penginderaan Jauh dan Interpretasi Citra, Yogyakarta: Gadjah Mada University Press, 1990. 